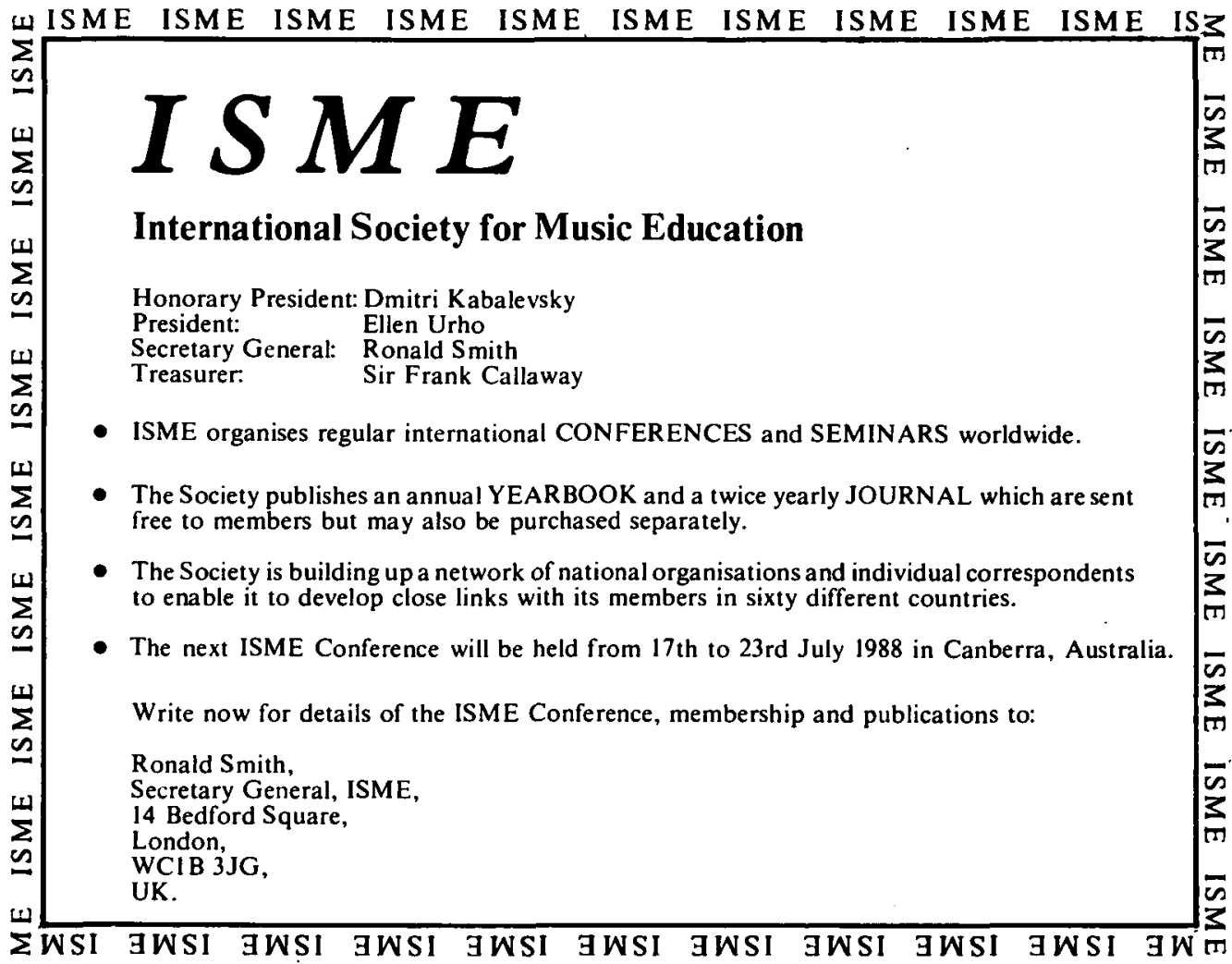




\section{BRITISH \\ JOURNAL OF \\ MUSIC \\ EDUCATION}




\section{BRITISH JOURNAL OF MUSIC EDUCATION}

\section{Editors}

PROFESSOR JOHN PAYNTER Department of Music, University of York, Heslington, York YO1 SDD

PROFESSOR KEITH SWANWICK Department of Music, University of London Institute of Education, 20 Bedford Way, London WC1H OAL

Review Editor

ANDREW PEGGIE $11 B$ Tregothnan Road, Stockwell, London SW9 $19 \mathrm{U}$

Editorial Board

JOANNA GLOVER Bath College of Higher Education

MARJORIE GLYNNE-JONES ILEA Music Centre

ANTHONY KEMP Music Education Centre, University of Reading

BRIAN LOANE ILEA Music Centre

WILLIAM SALAMAN University College, Cardiff

JAMES SLOGGIE Edinburgh

The British Journal of Music Education aims to provide clear accounts of current issues and research in progress and particularly to strengthen professional development and improve practice within music education. Editorial policy is to encourage careful reflection on teaching and learning in music and there is no commitment to any particular educational point of view or research style.

The British Journal of Music Education will be of interest to teachers, those concerned with administration in music education and others with an interest in the field.

Articles are invited and, where appropriate, may be of substantial length. Once a year a cassette of music examples will be produced and contributors may wish to take advantage of this to accompany their articles. Illustrations and photographs are welcomed.

Articles should be of interest to teachers of music, clearly written without unnecessary jargon and show evidence of careful and critical enquiry. Potential authors are referred to the notes for contributors (see inside back cover).

\section{(C) Cambridge University Press 1986}

Copying: This journal is registered with the Copyright Clearance Center, 21 Congress St., Salem, Mass. 01970. Organisations in the USA who are also registered with C.C.C. may therefore copy material (beyond the limits permitted by sections 107 and 108 of US copyright law) subject to payment to C.C.C. of the per copy fee of $\$ 05.00$. This consent does not extend to multiple copying for promotional or commercial purposes. Code 0265-0517/85/0000-0003\$05.00.

ISI Tear Service, 3501 Market Street, Philadelphia, Pennsylvania 19104, USA, is authorised to supply single copies of separate articles for private use only.

For all other use, permission should be sought from Cambridge or the American Branch of Cambridge University Press.

Subscriptions: British fournal of Music Education (ISSN 0265-0517) is published in volumes of three parts in March, July and November. The subscription price (which includes postage) of volume 3, 1986 is $£ 18.00$ (US $\$ 37.00$ in USA and Canada) for institutions, $£ 12.00$ (US $\$ 25.00$ in USA and Canada) or $£ 9.00$ (US $\$ 18.00$ in USA and Canada) for students, for individuals ordering direct from the Press and certifying that the journal is for their personal use. Single parts cost $£ 7.00$ net (US $\$ 16.00$ in USA and Canada) plus postage. Orders, which must be accompanied by payment, may be sent to a bookseller, subscription agent or direct to the publishers: Cambridge University Press, The Edinburgh Building, Shaftesbury Road, Cambridge CB2 2RU. Orders from the USA or Canada should be sent to Cambridge University Press, 32 East 57th Street, New York, NY 10022, USA. Second class postage paid at New York, NY, and at additional mailing offices. POSTMASTER : send address changes in USA and Canada to British fournal of Music Education, Cambridge University Press, 32 East 57th Street, New York, NY 10022. Copies of the journal for subscribers in the USA and Canada are sent by air to New York to arrive with minimum delay. 


\section{BRITISH \\ JOURNAL OF \\ MUSIC \\ EDUCATION}

VOLUME 3

1986

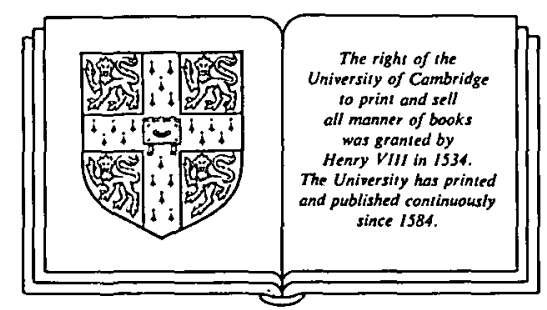

CAMBRIDGE UNIVERSITY

PRESS

CAMBRIDGE

LONDON NEW YORK NEW ROCHELLE

MELBOURNE SYDNEY 
Published by the Press Syndicate of the University of Cambridge

The Pitt Building, Trumpington Street, Cambridge CB2 1RP

32 East 57th Street, New York, NY 10022, USA

10 Stamford Road, Oakleigh, Melbourne 3166, Australia

(C) Cambridge University Press 1986

Printed in Great Britain by the University Press, Cambridge 


\title{
CONTENTS TO VOLUME 3
}

\author{
TABLE OF CONTENTS \\ BRITISH JOURNAL OF MUSIC EDUCATION
}

Vol. 31986

(Book reviews in italic letters)

NUMBER 1, MARCH 1986

Biographical Notes on Contributors 1

Editorial 3

Robert Kwami: A West African Folktale in the Classroom 5

Michael Taylor: Music Profiles - a Pilot Scheme 19

Sue Kendall: The Harmony of Human Life: An exploration of the ideas of Pestalozzi and Froebel in relation to music education 35

Yehezkel Braun: Traditional Harmony Reconsidered 49

Timothy Jones: Education for Creativity 63

Peter Renshaw: Towards the Changing Face of the Conservatoire $\begin{array}{ll}\text { Curriculum } & 79\end{array}$

Information $\quad 91$

$\begin{array}{ll}\text { Music for Piano } & 101\end{array}$

How to Play the Clarinet by Fohn Robert Brown 107

Teach the Clarinet by Nigel Keates 107

Braille Music - an International Survey by fohn Henry 109

Music Therapy by Fuliette Alvin 110

Therapy in Music for Handicapped Children by Paul Nordoff and Clive Robbins $\quad 110$

Books in Brief 113

NUMBER 2, JULY 1986

$\begin{array}{ll}\text { Biographical Notes on Contributors } & 117\end{array}$

$\begin{array}{ll}\text { Editorial } & 119\end{array}$

$\begin{array}{ll}\text { Call for Papers } & 121\end{array}$

Eddie S. Meadows: A Case for Music in Modern American Schools

Norman Mehr and Lu Elrod: Two! Four! Six! Eight! How do we Appreciate? Music Appreciation - Perceiving it, Understanding it

David J. Elliott: Finding a Place for Music in the Curriculum 135

Patricia K. Shehan: Towards Tolerance and Taste: Preferences for World Musics 
Elizabeth Oehrle: Creativity: Support for and Forces against this Basic Educational Idea in Western Music Education

Arthur W. Harvey: Is Brain Research Relevant for Music Education?

Ellen McCullough: Project Experience

Thomas A. Regelski: Concept-learning and Action Learning in Music Education

Sally Stone: An Analysis of Instructional Procedures in a College-Level Dalcroze Eurhythmics Class

Wind Bands and Brass Bands in School and Music Centre by Kevin Thompson

The Musical Mind: the Cognitive Psychology of Music by fohn $A$. Sloboda

Music in Action'85 (UK Council for Music Education and Training)

Composer in School Series (various authors)

Principles of Violin Playing and Teaching (2nd ed.)

by Ivan Galamian

Sing! (Books 1-4) by Heather Cox and Garth Rickard 246

Barnabas the Dancing Bear by Diana Holland 247

Count Me In (various contributors) 247

fuke Box (various contributors) 248

Kokoleoko by fune Tillman 248

Carols to Sing, Clap and Play by Heather Cox and Garth Rickard 248

Songs of Hoy by Peter Maxwell Davies 248

Books in Brief 251

NUMBER 3, NOVEMBER 1986

Biographical Notes on Contributors 255

Call for Papers $\quad 257$

Michael Miller: Sounds Useful: A Primary Music Project with the BBC Micro

Gerry Farrell: Teaching Indian Music in the West: Problems, Approaches and Possibilities

Coral Davies: Say it till a song comes (reflections on songs invented by children 3-13)

Graham F. Welch: A Developmental View of Children's Singing

Keith Swanwick and June Tillman: The Sequence of Musical Development: A Study of Children's Composition

Peter Owens: The Contemporary Composer in the Classroom 341

Notes on the Contents of the Cassette Tape 
Information

Music for Recorders

Young Strings in Action (vol. 1) by Sheila fohnson

Electronic and Computer Music by Peter Manning

Multi-mix Music by Ian Marshall

Ten Scenarios by Christopher Denman

Music for Mixed-ability Orchestra

Voices of Experience (Music Educators' National Conference)

A Realistic Rationale for Teaching Music by Charles Leonard

Policy Questions in Music Education by Samuel Hope

Teacher Competence and the Balanced Curriculum by Mary E. Hoffman

The Class of 2001: Coping with the Computer Bandwagon by Paul R. Lehman

Onward from Butler: School Music 1945-1985 by Bernarr Rainbow 373

Books Received 


\section{Notes for Contributors}

1a. All contributions ( 3 copies) and correspondence should be sent to either Editor: Professor John Paynter, Department of Music, University of York, Heslington, York YOr sDD, or Professor Keith Swanwick, Department of Music, University of London Institute of Education, 20 Bedford Way, London WCIH OAL.

rb. All material for review, and text of reviews, should be sent to the Review Editor, Andrew Peggie, IrB Tregothnan Road, Stockwell, London $\mathrm{SW}_{9}$ IJU. Only one copy of the review need be sent.

2a. Articles should be normally within the range 3,000 $-10,000$ words, although longer or shorter articles may be accepted by arrangements with the Editors.

2b. Reviews and surveys will have their lengths prescribed by the Review Editor, at the time of commissioning.

3. Contributions (articles, review articles, reviews) should be clearly typed on one side of the paper only (preferably A 4 size). All material should be typed double spaced with generous margins. In addition to the three copies submitted (one, in the case of reviews), contributors should keep a further copy of the typescript for correcting proofs.

4. Articles should be accompanied by a summary of approximately 100 words, together with information about the position/s held by the author/s and giving full details of any acknowledgements. In long articles, subheadings are encouraged.

5. All quotations and references should be identified in the text by author and date to link with the full references listed alphabetically at the end of the article. E.g. in the text, bracketed thus: (Self, 1976); in the alphabetical reference list thus: Self, G. 1976. Make a Nerv Sound. London, Universal Edition.

6. The full list of references should be typed, double spaced, on a separate sheet of paper at the end of the article. They must include the names and initials of all the authors cited (arranged in alphabetical order of the authors' surnames) and followed by (in the case of books) the date of publication, the title (underscored), the place of publication and the name of the publisher, or (in the case of articles cited) the date of publication, the full title of the article (not underscored), the name of the journal in which the article appeared (underscored), the volume number, issue number, and page number/s. Reference to an article which appears in a book should be made thus: the author's name, date of publication (in brackets), title of the article (in inverted commas), 'In' followed by author/s name(s) and title of the book (underscored), place of publication and name of publisher. E.g. Pollard, M. (1978). 'Folk Music in junior and middle schools'. In Leach, R. and Palmer, R.,
Folk Music in School. Cambridge, Cambridge University Press.

7. Notes other than bibliographical references should be given only when absolutely essential. These should be referred to in numerical order throughout the text and the number shown as superscript. The notes should then appear on a separate sheet of paper at the end of the article.

8. All necessary illustrations should accompany the typescript but should not be inserted in the text. All photographs, drawings and diagrams should be referred to as "figures" and should be numbered consecutively in the order in which they are referred to in the text. A list of captions should be provided on a separate sheet. Photographs should be well-contrasted prints with glossy finish (preferably $10^{\prime \prime} \times 8^{\prime \prime}$ ), if possible mounted on thin card. Each should have, lightly written on the back with felt-tipped pen, the author's name and the figure number. Authors to whom first-class photographic facilities are not available are encouraged to send both marked contact prints and the negatives under registered cover. Drawings and diagrams should be done in indian ink on strong paper, white card, or good-quality tracing paper.

9. A cassette tape of 40 minutes maximum duration will be available once a year, normally accompanying every third issue of the British Journal of Music Education. Contributors may wish to avail themselves of this opportunity to present musical examples, even if these refer to articles which have appeared in either of the two previous issues. Recorded material must be submitted in its final edited form (on cassette or open-reel). To facilitate transfer to the published tape, it will be helpful if contributors could ensure that the master tapes are of the highest possibie quality. Individual items on the tape should be identified by aural cues which will correspond with a typewritten list. The author's name should be clearly written on each tape and tape box.

10. Proofs of all articles accepted will be sent to authors for correction of typographical errors only. Failure to return proofs within the specified deadline may lead to the Editors sending their own corrected proofs to the printer without further reference to the author.

x. Twenty-five offprints will be supplied free of charge to authors on publication of a paper. These must be shared in case of joint authorship. Additional offprints may be purchased if ordered at proof stage.

12. Authors will be requested to assign their copyright to Cambridge University Press to protect their rights and those of the Journal. Authors are responsible for obtaining any necessary permissions to quote copyright material in their article. 


\section{BRITISH JOURNAL OF MUSIC EDUCATION}

\section{Volume 3 Number 3, November 1986}

\section{CONTENTS}

Biographical Notes on Contributors $\quad 255$

Call for Papers $\quad 257$

Michael Miller: Sounds Useful: a Primary Music Project with the BBC

Micro

Gerry Farrell: Teaching Indian Music in the West: Problems,

Approaches and Possibilities

Coral Davies: Say it till a song comes (reflections on songs invented by children 3-13)

Graham F. Welch: A Developmental View of Children's Singing

Keith Swanwick and June Tillman: The Sequence of Musical

Development: A Study of Children's Composition

Peter Owens: The Contemporary Composer in the Classroom 34I

Notes on the Contents of the Cassette Tape $\quad 359$

Information

BOOK REVIEWS

C) Cambridge University Press 1986

Cambridge University Press

The Pitt Building, Trumpington Street, Cambridge CB2 IRP

32 East 57th Street, New York, NY 10022, USA

Io Stamford Road, Oakleigh, Melbourne 3166, Australia

Printed in Great Britain by the University Press, Cambridge 